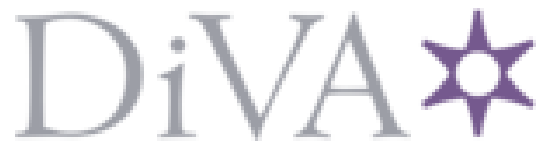

http://www.diva-portal.org

This is the published version of a paper published in The Gerontologist.

Citation for the original published paper (version of record):

Zamorano Llena, C. (2018)

Looking Very Old Age in the Eye: A Nuanced Approach to the Fourth Age in Contemporary Irish Fiction. A Case Study

The Gerontologist

https://doi.org/10.1093/geront/gnyo35

Access to the published version may require subscription.

N.B. When citing this work, cite the original published paper.

Permanent link to this version:

http://urn.kb.se/resolve?urn=urn:nbn:se:du-25813 


\title{
Looking Very Old Age in the Eye: A Nuanced Approach to the Fourth Age in Contemporary Irish Fiction: A Case Study
}

\section{Carmen Zamorano Llena, PhD*}

School of Humanities and Media Studies, Dalarna University, Falun, Sweden.

*Address correspondence to: Carmen Zamorano Llena, PhD, School of Humanities and Media Studies, Dalarna University, 79188 Falun, Sweden. E-mail: cza@du.se

Received: September 5, 2017; Editorial Decision Date: March 22, 2018

Decision Editor: Helen 0. Kivnick, PhD

\begin{abstract}
Background and Objectives: Associations of young-old age with successful aging have contributed to relegating negatively perceived aspects of aging to very old age. This has prompted the formation of the social imaginary of the fourth age. Re-examinations of the fourth age foreground the diversity of aging experiences among the oldest old. In this sense, literature is in a privileged position to contribute individual narratives of aging to this field. The main aim of this article is to analyze Irish writer Jennifer Johnston's later fiction and how particularly two of her later fictional works contribute a nuanced re-examination of the fourth age through the narrativization of individual aging experiences of the oldest old in the contemporary Irish context.

Research Design and Methods: The work of sociologists and social theorists on re-examinations of the fourth age functions as the framework to analyze the selected fictional texts.

Results: The analysis of the oldest old characters in Truth or Fiction and Naming the Stars shows the contribution of literary texts to rethinking the fourth age as a time characterized by the inextricable combination of gains and losses, with emphasis on the diversity of the aging experiences of the oldest old and on the importance of sociocultural influence on individual aging.

Discussion and Implications: Combining longitudinal analyses with case studies, such as the ones suggested by these fictional texts, can provide a more accurate knowledge of the experience of advanced old age and the fourth age.
\end{abstract}

Keywords: Fourth age, Contemporary Irish literature, Literary gerontology, Narrativization of individual aging experience

\section{Introduction: Contributing to Fourth Age Studies Through Literary Gerontology}

In 1926, the Irish poet William Butler Yeats (1926), in his early sixties, proclaimed "That is no country for old men. The young / . . . / . . . all neglect / Monuments of ageing intellect" ("Sailing to Byzantium," 1968, p. 104). These lines, which are a reflection of Yeats's life-long artistic and existential preoccupation with aging, articulate what he regarded as the nearly irreconcilable differences between the world of the young, deictically distant from the persona as suggested by the opening "That" in the poem, and the world of the old, which was relegated to the margins of the dominant reign of the young. However, nearly a century after Yeats's bleak pronouncement, it can conclusively be claimed that "that" dominance of the world of the young is - at least in numerical terms-no more, for the aging of the global population is here to stay. As the 2002 UN report World Population Ageing 1950-2050 observed, “by 1998 the historic reversal in relative proportions of young and old had already taken place in the more developed regions," 
and, as the report ominously contended, "the young populations of the past are unlikely to occur again" (2002, pp. xviii-xxix).

For the last six decades population aging has been a source of particular and increasing concern in the political arena at a global level. This time frame is often established on the basis of the United Nations' first official report on population aging and its social and economic consequences, (United Nations, 1956). The aging of the global population is deemed to be one of the most dramatic societal changes of the twenty-first century and an irreversible trend. One of the most significant features of this global phenomenon is the rapid aging of the aging population, which was already remarked upon in the 2002 UN report and expanded in the World Population Ageing 2015 UN report. It is estimated that by 2050 the oldest old (those aged 80 years and over) will have more than tripled in number since 2015 (UN, Population Division, 2015, p. 2); whereas at the turn of the twenty-first century this segment of the population represented one tenth of older people (those aged 60 years and over), by 2050 it is estimated that it will stand for one fifth (UN, Population Division, 2002, p. xxix).

In the fields of gerontology and age studies, this rapid aging of the aging population has gained increasing critical attention and has led to the revision of the manner in which old age has been analyzed in what is, in retrospect, perceived as an overly generalizing approach to this increasingly longer period of later life. Two of the key actors in this revisionary approach to the study of old age, Paul B. Baltes and Jacqui Smith, have observed the need to distinguish between a third age and a fourth age in order to reach a better understanding of the development of the aging population (Baltes \& Smith, 2003, p. 124). Their distinction is based on the concepts of young-old and old-old, which were first introduced by psychologist Bernice L. Neugarten (1974) and historian Peter Laslett (1989). Significantly, and in line with the development of aging at the time in which these scholars produced their research, their work focused on the analysis of the third age (identified by Neugarten as between the ages of 55 and 75), which was characterized by a positive approach to the possibilities of youngold age. This was not only in terms of improved individual quality of life, but also because of the potential for the young-old to become, as Neugarten contended, "agents of social change in creating an age-irrelevant society and in thus improving the relations between age groups" (1974, p. 187). Baltes and Smith's (2003) ground-breaking work in identifying the "multiple ages of old age" (p. 124) and the peculiarities of the young-old also implicitly contributed to a polarized view of the third and the fourth age, in which the latter was defined as "a period of decrepitude that particularly affected those who lived beyond their mid-80s" (Higgs \& Gilleard, 2015, p. 41). Baltes and Smith (2003) inherited and perpetuated this polarized perception of the third versus the fourth age, according to which " $[t]$ he good news about aging is the news of the third age" (2003, p. 127); what lies beyond young-old age is a barren valley marked, as they conclude, by "a high prevalence of [physical and psychological] dysfunction and reduced potential for enhancement of function" (2003, p. 133). More recent work on the fourth age, however, has focused on the analysis of ways in which a more nuanced view of very old age can be produced, which acknowledges its distinctiveness as well as the diversity in the manner in which this old-old age is experienced.

Social theorists Paul Higgs and Chris Gilleard's (2015) work on the fourth age explores possibilities to subvert the negative view of aging that is often associated with very old age. They do so by defining the fourth age as a "social imaginary," namely "a product less of nature than of the "social mind," which is often depicted as negative, "that old, 'real' old age which we have always feared" (2015, p. viii). Thus, whereas earlier scholars (Baltes \& Smith, 2003; Laslett, 1989) based their distinction between the third and the fourth age on statistics and biological factors, thus allowing for the identification of an age bracket at which the transition into the fourth age was said to occur, Higgs and Gilleard contend that the fourth age is socially constructed as a process of "othering" old-old age which enables the preservation of the third age as an image of "active, healthy, productive or successful aging" (2015, p. vii). In order to produce this imaginary of the successful aging of the third age anything that is feared, hideous and abject about aging is displaced into the area of willing unknowability relating to physical, psychological, and social decline of old age. This becomes the construct of the fourth age, namely "a collectively imagined terminal destination in life-a location stripped of the social and cultural capital of later life which allows for the articulation of choice, autonomy, self-expression, and pleasure" (Higgs \& Gilleard, 2015, p. 14). The main way to combat the fear of the unknown "'deep', 'real' or 'frail' old age" (Higgs \& Gilleard, 2015, p. 19) is by producing research that casts light on the reality and specificity of the fourth age so as to offer a more balanced view of the diverse experiences of very old age.

In literary gerontology, the aim to counter negative cultural constructs of aging and to expose the adverse effects of such images on individual perceptions of aging as represented in literature has inspired many of the seminal studies in the field. As a number of scholars have acknowledged, literary gerontology may at times admittedly have been spurred by a positivist approach to the potentialities of aging (Falcus, 2015). In this sense, in Aged by Culture (2004), cultural critic Margareth Morganroth Gullette self-critically acknowledges that her seminal study Safe at Last in the Middle Years (1988) had been guided by what she calls her "tic-a cultural tropism-of looking primarily for signs of progress" (2004, p. 28). Gullette concludes that "[a]lthough the politics of optimism and resilience is appropriate when we focus on resisting age ideology, at this stage of our examination of culture and the economy we must be nuanced and precautionary" (2004, p. 28). This need for nuance, which is essential in order to foreground 
the complexities of the aging experience, has guided the work of literary gerontologists as well as recent developments in this field. In Figuring Age (1999), for example, Kathleen Woodward notes the need to move away from essentialist discourses that disregard the diversity of the aging experience in women $(1999, \mathrm{p}$. xiv), and concludes her introduction to this collection of essays remarking on the need for greater diversity in the analysis of the focus theme of her study, namely women, bodies and generations (1999, p. xxiii). Besides, the recent engagement of literary gerontologists with illness and disability studies (Hartung, 2016; Swinnen \& Schweda, 2015) purportedly contributes not only to complicating facile associations of illness and disability with undesirable old age, but it also furthers the realization that aging, particularly in relation to very old age, is necessarily an experience of gains and losses. This is in line, not only with Erik Erikson's principle of dynamic Balance of Opposites regarding individual psychosocial development throughout the life course (Kivnick \& Wells, 2014), but also with philosopher Jan Baars's (2010) “dialectic of loss and gain" (2010, p. 106). According to Baars, a binary understanding of the aging experience is the result of "fears caused by the insecurities of future life in which an uncertain future of aging is not looked in the eye" (2010, p. 108). In his probing into what he terms "the dialectic of loss and gain" (2010, p. 106), Baars calls for the need to understand that what are popularly perceived as gains and losses of aging are, in fact, interrelated processes, and that the negative aspects should not be "denied the dignity and careful attention they deserve [as] aspects [that] are inherent in human life" (Baars, 2010, p. 108).

One of the factors that require complexity and nuance of analysis of the oldest old is precisely the diversity of experience that is particular to fourth agers (Age UK, 2012). As Poon and Cohen-Mansfield (2011) observe in their study of well-being in the oldest old, "the large amount of individual variability within the cohort... makes it difficult to reach generalizations for the group," which, according to these authors, may also account for "the lack of exploration into the well-being of individuals in the fourth age" (p. 4). This lack of sufficient analysis of the fourth age (Age UK, 2012; Tomassini, 2005) suggests the need to approach the study of the oldest old in a manner that is characterized by the importance of attending to their individualized experience through the use of longitudinal, qualitative studies. It is in this sense that the use of literary narratives is particularly pertinent, not only because they can provide an insight into imagined experiences of aging in very old age, but also because of their transformative potential. As Wyatt-Brown (2010), literature and its scholarly study through literary gerontology help "comprehend the varieties of aging experience in our time," particularly as "[n] arratives have the capacity to create a picture of aging, one that most readers can easily understand and appreciate" (p. 57). Renowned literary gerontologist Barbara Frey Waxman goes even further when articulating her understanding of the role of literature and literary criticism in relation to aging. She contends that "[1]iterary texts not only entertain, not only reflect the society in which they are produced, but also are capable of changing people's attitudes and politics, of influencing the world," while literary critics "may be able to capture a wider audience and have more of an impact on how people read-and how they afterward might behave, thereby revealing how texts work to initiate cultural change" $(2010$, pp. 83,84$)$. It is in line with this understanding of the potential of literature and literary gerontology to effect cultural changes that the present analysis of Jennifer Johnston's two literary texts is situated. This view regarding the potential cultural benefits to be obtained through literary gerontology has also inspired existing research. Thus, Oró-Piqueras (2016) and Goldman (2017) are relevant examples of the manner in which literary gerontology contributes to the representation of the complexities of the aging experience. Goldman's study is particularly relevant to the present work as a recent example of critical engagement with Higgs and Gilleard's (2015) analysis of the fourth age, though from the perspective of the interrelationship between literary gerontology and illness and disability studies. This article thus contends that the study of the oldest old characters in Irish writer Jennifer Johnston's Truth or Fiction (2009) and Naming the Stars (2015) provides an insight into the distinctive and individualized experience of the very old, which can also contribute to the type of cultural change that, as Higgs and Gilleard claim, is required to reimagine the social imaginary of the fourth age.

\section{Truth or Fiction: An Oldest Old Character's Regard of "Extreme Old Age" as "Not to Be Recommended"}

Johnston's Truth or Fiction starts with a first-person, middle-aged English female narrator, Caroline Wallace, recounting her frustrated expectations for a conventional life- "I would have liked to have had a couple of babies, a dog and a cat" (Johnston, 2009, p. 3)—which she regards as unrealizable at the age of 45 . Having set the stage for the conflict to come, the narrative moves to the third-person at the point in which Caroline, a literary journalist, is commissioned to write a feature piece on Desmond Fitzmaurice, a nonagenarian Irish dramatist living in Dublin who has been ignored by the public for years, if not decades. This task, for which Caroline has to leave London in order to visit the writer over the course of a couple of days, coincides with a crisis point in Caroline's life. This crisis erupts when Herbert, a writer by trade and her partner of ten years, unexpectedly proposes to her one morning when stepping out of the bath, because that would be his "prize" after completing his latest book. This marriage proposal, as blasé and untimely as it is prosaic, enrages Caroline, who departs for Dublin undecided as to what her response will be. From this point on, the third-person narrative pitches Caroline's 
midlife critical point against Desmond's aging experience, which maintains the narrative focus for the remainder of the novel.

By right of age, Desmond unquestionably belongs to the oldest old, the most rapidly growing group in Ireland (Department of Health, 2013, p. 7). However, his adscription to this group is not merely based on his biological age, but rather on the manner in which he experiences his own very old age, as it is socioculturally defined. Thus, from his first encounter with Caroline, Desmond displays some crystalline insight into the manner in which his old age is construed from the perspective of younger eyes, a process which disempowers fourth agers by having their experience recounted, as Higgs and Gilleard note, as "third person narratives" (2015, p. 120). Thus, the choice of narrative voice in this literary text foregrounds the process of othering implicit in common representations of the fourth age as characterized by frailty, the death of the social and the loss of agency, in short, all those elements that are imagined from the perspective of younger generations as a state to be feared, "a source of contamination, disgust and otherness, a 'dirty' old age threatening all who come close to it" (Higgs $\&$ Gilleard, 2015, p. 78). Desmond's accurate understanding of this othering discourse is what enables him to adroitly discern the cause of Caroline's awkwardness during their first meeting, which leads him to enquire: "Are you frightened of me?," adding that "[y]oung people are sometimes frightened of old people. It's not necessary, you know. I am not a frightening man. By no means" (Johnston, 2009, p. 27). The fear that Desmond knows to be associated with what he calls his "extreme old age" (p. 12) has its roots in the collective imaginary that has pushed the abject aspects of aging into the recesses of a collective unconscious which Higgs and Gilleard (2015) have likened to a black hole. As these social theorists contend, the gravitational pull of this metaphorical black hole generates the "event horizon," namely "a point where light disappears completely" (p. 16). As they observe, "the fear of the fourth age is a fear of passing beyond any possibility of agency, human intimacy or social exchange of becoming lost in the death of the social, a hyper-reality from which there is no reality to return to" (Higgs \& Gilleard, 2015, p. 16).

In the case of Desmond's fourth age, he is aware of the manner in which advanced old age is associated with a "social death" that renders him invisible, at best, abject, most often than not. The definition of social death has been traced back to French sociologist Robert Hertz's use of the term in an essay written in 1907. In this essay, Hertz refers to the fact that death does not only involve the termination of biological life, but also of the individual's social presence, which would often follow biological death. However, the increase in life expectancy and the aging of the aging population have implied the association of social death with very old age, thus preceding biological demise (Lloyd, Calnan, Cameron, Seymour, \& Smith, 2012; Sweeting \& Gilhooly, 1992; Sweeting \& Gilhooly, 1997, p. 96).
According to Sweeting and Gilhooly (1997), this association of very old age with social death is explained by the fact that "in Western industrial societies great value has been placed on the productive contribution of individuals" (p. 96). In the case of Desmond, his lack of creative output as a writer in later years has led him to this type of social death, as suggested by Caroline's Literary Editor, when she remarks: "No one reads his books any more, no one puts on his plays, no one in fact knows his name, except, of course, the odd expert like yourself" (Johnston, 2009, p. 4). Desmond's awareness of this social annihilation explains his almost desperate attempts at eluding its grasp on his individual sense of identity. It is in this sense that Caroline's commissioned work comes to symbolize for him a plank of salvation, the hope of being rescued from his social and public death. As Desmond sombrely observes: "For years they have called me cold and grey. For years they have decided that I was dead. I don't suppose that any of my books are in print any longer. You can change all that. My future is in your hands" (Johnston, 2009, p. 32). It is this mere prospect of social and public resuscitation that has a direct effect on his subjective well-being, understood as based on the individual's self-perception (Poon \& Cohen-Mansfield, 2011, p. 4): "I feel quite buoyed up. The thought of a rosy future has cleared my mind" (Johnston, 2009, p. 33). The amelioration of Desmond's circumstances and subjective well-being are thus implicitly dependent on Caroline. This accentuates the representation of this oldest old character as lacking in agency and self-reliance, a lack often associated with the fourth age. It must be noted, however, that this lack is not inherent to Desmond's personality, but rather an attribute of the social construct of the fourth age which has been projected onto Desmond in his very old age, which has consequences on his subjective well-being.

Desmond is purposefully constructed as an unsympathetic character, which initially facilitates the association of his persona with the abject. He is depicted as a womanizer in his young age, with an oedipal relationship to his mother, a self-absorbed despot to his second wife Anna, whom it is suggested he has physically abused at least once in his old age, and who obsessively and secretly records his memories using an old tape-recorder. This negative depiction is supplemented with Desmond's manifest dissatisfaction with his experience of advanced old age. He regrets the loss of physical and mental faculties, which he considers to be "inadequacies" of old age (Johnston, 2009, p. 27), and has been unable to maintain a social network, as he is on bad terms with his three children, and only sees regularly his ex-wife Pamela and a taxi driver who served with him during the Second World War. His views on aging and his life prospects suggest a loss of a joie de vivre. Thus, in a conversation with his first wife Pamela, he unabashedly complains about old age: "I hate old age, stiff and creaky, cranky, smelly" (Johnston, 2009, p. 42), and commenting on his wife's control over his diet, he observes: "she believes that with her help I will live forever. I do hope she's wrong” (Johnston, 2009, p. 30). 
Desmond's subjective perception of his aged self is purportedly not uncommon among the oldest old. Analyses of the degree of life satisfaction in the oldest old register a dramatic decrease among this group. As contended by Smith, Borchelt, Maier, and Jopp (2002), "[i]t is suggested that the increased risk of frailty, loss of functional capacity, and poor health during the period of very old age ... may place constraints on life satisfaction and overwhelm individuals to such a degree that they moderate their expression of well-being" (p. 719). In his case, it is particularly relevant that, despite experiencing the normal, though not the worst, "inadequacies" of extreme old age, Desmond's low life satisfaction allegedly originates both in the social death which he endures as a consequence of his very old age, and in the psychological distress caused by his regretful re-examination of crucial and irreversible events in his young life which resulted from his dubious moral and ethical system. These events include the loss of what he regards as the love of his life and his cold-blooded, casual shooting of a Nazi officer the day after the end of the Second World War. By the end of the novel no resolution to these haunting memories is attained, which, together with the imposition of social death on his persona, has a direct effect in Desmond's sense of subjective well-being. Consequently, the narrative does not suggest a sense of growth through reminiscence and life-review conducive to successful aging, as is often observed from the perspective of this paradigm (Bohlmeijer, Roemer, Cuijpers, \& Smit, 2007; Butler, 1974).

The narrativization of Desmond's experience of aging is significantly characterized by a mismatch between his explicit distaste with the effects of very old age, on the one hand, and his performance as a fully agentive fourth ager, on the other. Thus, for example, his insight into the manner in which social discourse others him on the basis of his advanced age belies a degree of mental alertness that counters the frailing discourse of the social imaginary of the fourth age. In terms of his physical condition, the fact that he still lives at home with his wife, and can move around Dublin without any help or support, apart from using the service of his friend as a taxi driver, suggests a degree of physical independence that clashes with his perception of old age as "stiff and creaky" (Johnston, 2009, p. 42). Regarding his social self, this has certainly been reduced with age, but he still has his wife and meets up regularly with his first wife, as well as with his former war companion. Thus, the clash between Desmond's self-expression about his old age and his own physical and intellectual performance as an oldest old serves to underscore that there has been a certain degree of interiorization of the social imaginary of the fourth age, and an experience of extreme old age under the influence of this imaginary that affects his sense of self when faced with what he perceives as the "precariousness about the present," as suggested by his reflections upon aging (Lloyd et al., 2012, p. 10).

\section{Naming the Stars: Reminiscence and Sociocultural Context, Not (Necessarily) Conducive to Successful Aging}

Johnston's novella Naming the Stars (2015) revolves around the narrative of two female characters, Flora and Nellie, which is mostly dominated by the latter's reminiscing of the circumstances that explain her life development and present state of near confinement. Flora, the last known surviving member of an Anglo-Irish family, and her lifelong maid Nellie, are the only inhabitants of the family's old country house. The narrative is set in contemporary Ireland, though the physical setting and the choice of protagonists is reminiscent of the Big House novel, a characteristically Irish literary subgenre which focuses on narrating the gentry life of the Protestant ascendancy, a social class identified with the plantation processes of the 16th and 17th centuries and, therefore, with the colonial presence of the English in Ireland. As literary critic Vera Kreilkamp (1998) contends, one of the characteristic features of these novels is that they imply a dialogic engagement of the fictional narrative with the historical narrative of this social class and their historical moment (p. 3). Johnston's novella contains elements of this literary subgenre, such as the sense of a social class that was dying out at the time in which these novels were written, and the presence of childless aged female characters belonging to this class as well as pseudoderelict country houses as symbols of this class on the wane. However, Johnston's text relegates to the background the "responsiveness to issues of national identity that distinguishes the nineteenth-century Irish novel" (Kreilkamp, 1998, p. 5), and foregrounds instead the aging experience of its protagonist. The narrative examines how the sociopolitical and cultural circumstances not just in Flora's late life, but also in her earlier life are decisive in her development and, ultimately, in her experience of advanced old age. To a certain extent it can be argued that, by focusing on the development of the female aged protagonist, this novella shares with the literary subgenre of the Big House novel the "responsiveness" to sociocultural developments in the national context of contemporary Ireland. In Johnston's text, however, this does not relate to matters of national identity, but rather to national concerns regarding the exponential growth of those aged 80 years and over, which have become increasingly present in the Irish political agenda over the last few years (e.g., Department of Health's Positive Ageing, 2013; Health Service Executive's "Healthy and Positive Ageing for All” Research Strategy, 2015-2019). To illustrate the origin of these concerns, it may suffice to note that it is estimated that, in the Republic of Ireland, whereas in 2006 the number of those aged over 60 was 462,000 people, by 2036 there will be a $250 \%$ increase and by 2041 it will have tripled. The greatest increase is, however, in those aged 80 years and over, where it is estimated that, compared with the population in this group in 2006, by 2041 the 
population will have quadrupled (Ageing Well Network, 2012, p. 39).

The two female characters featured in this novella are in their eighties and, though Flora is 5 years younger (Johnston, 2015, p. 87), Nellie is seemingly a living example of "active aging," as she takes care of all house chores, runs any errands on her bicycle and takes care of Flora, with whom, as apparent from their conversation, she has developed a sense of mutual close companionship. Despite the lack of any evident physical impediment, Flora is noticeably inactive, with her existence confined to the limits of her Big House. Over the course of a single September evening, Flora's reminiscence gradually unveils psychological trauma in childhood and early adolescence as the possible explanation for her secluded existence. This experience relates to examinations of adult development models and the extent to which distal influences and past traumatic experiences may impact on life development and subjective well-being in advanced old age (Cho, Martin, \& Poon, 2015; Martin, da Rosa, \& Poon, 2011; Shmotkin, Shrira, \& Palgi, 2011). In the case of Flora, there are two specific traumatic experiences that, as revealed through her reminiscence, have affected her "developmental trajector[y]" (Cho et al., 2015, p. 133). The first of these experiences is the loss, at the front during the Second World War, of the two family members to whom she was most closely attached, namely her father in El Alamein, North Africa, and Eddie, her only sibling and elder brother, in Normandy, just 2 years after the tragic loss of their father when she was in her early teens. It is intuited that the dramatic damage to Flora's subjective well-being, caused by these losses at a crucial developmental stage in her life course, led to her mental instability and consequent institutionalization. However, the fallacy of this official narrative of Flora's life, as well as the actual trauma that explains her present circumstances are revealed in the secret that Flora unveils to Nellie, namely her pregnancy resulting from a one-night incestuous intercourse with her brother, under the effects of alcohol, trauma, and isolation, the night before he left the family home to secretly volunteer for war service.

Flora's trauma, however, was not caused by the personal experience of being made pregnant by her brother, but by the socialization of this circumstance under the restrictive conservative morality of Ireland at the time. It is in this sense that a consideration of the sociocultural conditions of an individual's aging becomes crucial in order to gain a more nuanced understanding of subjective well-being in old-old age as well as the reasons behind an individual's apparent failure to age successfully. As Riley (1998) observed in her criticism of Rowe and Kahn's 1997 revision of their successful aging paradigm, "it fails to develop adequately the social structural opportunities necessary for realizing success" (p. 51). In this sense, Riley contends that "successful ageing [depends] upon structural opportunities in schools, offices, nursing homes, families, communities, social networks, and society at large" (1997, p. 151). In Johnston's novella, Flora stands as a case in point of the negative consequences for individual aging when these micro, meso, and macro social structures fail to offer the necessary support to deal with psychological distress in an adequate manner. Thus, upon discovering Flora's pregnancy, she is confined by her mother to a mental institution, which Flora refers to as a "home from home for the harmlessly insane" (Johnston, 2015, p. 76), and which is evocative of the ignominious Magdalene asylums (Finnegan, 2001), mid-nineteenth-century homes initially aimed for the reformation of prostitutes. However, in later years, these institutions also de facto incarcerated other “'fallen' women—sexually active, unmarried women; victims of rape, incest and abuse; and women convicted of infanticide or concealment of a birth-as well as women considered to be at risk for a moral fall because they were too pretty, mentally disabled or ill, ..." (Scarlata, 2014, p. 204). Although initially established as social institutions by Protestant reformers in colonized Ireland, in the Irish context, the running of these institutions was taken over by Roman Catholic orders after the establishment of the Irish Free State in 1922 (Scarlata, 2014, p. 204), when these institutions were turned into commercial laundries as a source of income for the orders that run them. These institutions functioned until 1996, when the last Magdalene laundry closed in Waterford city, in southern Ireland. Although Flora initially does not relay the father's name, upon revealing it, Flora is tagged as "mad," or temporarily mentally disabled, and in need of being stabilized before being released. In this manner, the restrictive social mores in 1940s Ireland enabled her mother and the institution to which she was confined to take recourse to the medical model of disability, which often regards it as "a personal tragedy that can sometimes lead to the blaming of the individual for his or her condition and the labelling of people with disabilities as 'victims' or 'sufferers'” (Bond \& Rodríguez Cabrero, 2007, p. 118). As Bond and Rodríguez Cabrero (2007) contend, in this process of medicalizing disability, " $[\mathrm{t}]$ he solution for the individual is perceived as medical treatment in order to 'cure' the condition, manage the symptoms and maintain the individual's adjustment to the disability and subsequent behaviour change" (p. 118). As a result of this medicalization of what was socially regarded as immoral—and illegal, according to the Punishment of Incest Act 1908-behavior, Flora is confined to this institution for the duration of her youth and most of her adult life. When released aged 49, and only after her mother's death, she returns to the family home, which she never leaves again, avowedly as a consequence of her long-term institutionalization.

As with Desmond in Truth or Fiction, Nellie's reminiscence concludes with no obvious acquisition of wisdom or discernibly positive outlook towards the future. In this sense, both fictional texts subvert the expectations of Constance Rooke's Vollendungsromane (Rooke, 1988). Rooke's classification of the novels of completion or "winding down" identifies as characteristic of these texts an aged 
protagonist who, often through reminiscing and reviewing crucial past events, "is able to impart some wisdom regarding the end of life" (Hobbs, 2016, p. 110). This wisdom also frequently allows these characters to attain a sense of "personal completion" and to reengage with their existence in a manner that suggests the realization of gerotranscendence, which Lars Tornstam (1997) defines as "a shift in metaperspective from a materialistic and rational view of the world to a more cosmic and transcendent one, normally followed by an increase in life satisfaction" (p. 15). Desmond's and Flora's narratives do not suggest a gerotranscendent approach to their existence. Even Flora's final scene, naming the stars with her companion Nellie, reeks of escapism rather than inviting a more positivistic, cosmic connection with her existence and her place in the universe. This is particularly the case as naming the stars was a pastime of Nellie after watching Hollywood films in the local cinema in her youth, an activity which, as Nellie observes, would allow her to "touch ... the world, not just [being] stuck at the bottom of a muddy hill in County Wicklow" (Johnston, 2015, pp. 13-14). This apparent cosmic connection functioned rather as an imaginative escape which would sweep her away from her everyday life as a young maid in the Big House where she ended up spending the rest of her life.

\section{Conclusion}

In recent years, the exponential growth of the oldest old population has attracted increasing scientific interest in this segment of the population, which had remained largely unexamined. Analyses of the oldest old and the social imaginary of the fourth age have emphasized, among other factors, the need to pay greater attention to the diversity of individual experiences of aging and to consider the sociocultural conditioning of aging. They have emphasized the need to gain greater awareness of the different ages of old age, and to analyze, in particular, the specificity of advanced old age, remarking on the high degree of variability relating to the subjective experience of aging among the oldest old. This diversity, however, has not always been reflected in longitudinal studies (Marcoen, Coleman, \& O’Hanlan, 2007, p.61). This is one of the reasons why a combination of this type of analyses with case studies can provide a more accurate knowledge of the experience of advanced old age. This will consequently offer a more nuanced understanding of this period of late life, which will ascribe more concrete knowledge to the fearful unknowability of the fourth age and thus contribute to rethinking this social imaginary. In this sense, literature, as exemplified here with the case of Johnston's texts, can fruitfully contribute fictional narratives of aging individuals who, like Desmond and Flora, would otherwise fall through the gaps of studies of old age. Their stories are a necessary component in order to gain a more mature understanding of how aging, and particularly advanced old age, incorporates gains and losses, and of the fact that the manner in which these are experienced varies individually and in relation to sociocultural and historical conditioning.
With regard to this mature perspective, when asked in an interview whether the marriage between the characters of Laura and Maurice as described in her novel The Invisible Worm (1992) is "positive," Johnston replied: “It's mature. In the real world, people have to compromise. Life is a series of complex negotiations" (Moloney, 1998, p. 145). Through the individual aging experience of her oldest old characters of Desmond and Flora, Johnston's latest fiction highlights the need for this "series of complex negotiations" between gains and losses, positive and negative experiences of aging, to be incorporated into scholarly analyses of narrativizations of the aging experience. In line with Baars's advice, Johnston's fictional texts look advanced old age in the eye in order to contest the frailing and abjection of the fourth age.

\section{Funding}

None reported.

\section{Acknowledgments}

None reported.

\section{References}

Age UK. (2012). Improving later life: Understanding the oldest old. Retrieved from https:/www.ageuk.org.uk/globalassets/ageuk/documents/reports-and-publications/reports-and-briefings/ health--wellbeing/rb_feb13_understanding_the_oldest_old_ improving_later_life.pdf (accessed March 2, 2018).

Ageing Well Network. (2012). The new agenda on ageing: To make Ireland the best country to grow old in. Dublin. Retrieved from https://ec.europa.eu/eip/ageing/library/new-agenda-ageing-makeireland-best-country-grow-old_en (accessed March 2, 2018).

Baars, J. (2010). Philosophy of aging, time, and finitude. In T. R. Cole, R. E. Ray, \& R. Kastenbaum (Eds.), A guide to humanistic studies in aging: What does it mean to grow old? (pp. 105-120). Baltimore: John Hopkins University.

Baltes, P. B., \& Smith, J. (2003). New frontiers in the future of aging: From successful aging of the young old to the dilemmas of the fourth age. Gerontology, 49, 123-135. doi:10.1159/000067946

Bohlmeijer, E., Roemer, M., Cuijpers, P., \& Smit, F. (2007). The effects of reminiscence on psychological well-being in older adults: A meta-analysis. Aging \& Mental Health, 11, 291-300. doi:10.1080/13607860600963547

Bond, J., \& Rodríguez Cabrero, G. (2007). Health and dependency in later life. In J. Bond, S. M. Peace, F. Dittman-Kohli \& G. Westerhof (Eds.), Ageing in society: European Perspectives on Gerontology (pp. 113-141). London: Sage.

Butler, R. N. (1974). Succesful aging and the role of the life review. Journal of the American Geriatrics Society, 22, 529-535. doi:10.1111/j.1532-5415.1974.tb04823.x

Cho, J., Martin, P., \& Poon, L. W.; Georgia Centenarian Study. (2015). Successful aging and subjective well-being among oldest-old adults. The Gerontologist, 55, 132-143. doi:10.1093/ geront/gnu074

Department of Health. (2013). Positive ageing - Starts now!: The national positive ageing strategy. Dublin: Government of Ireland. 
Falcus, S. (2015). Literature and ageing. In J. Twigg \& W. Martin (Eds.), The Routledge handbook of cultural gerontology (pp. 53-60). London: Routledge.

Finnegan, F. (2001). Do penance or perish: Magdalen asylums in Ireland. Oxford: Oxford University Press.

Goldman, M. (2017). Re-imagining dementia in the fourth age: The ironic fictions of Alice Munro. Sociology of Health \& Illness, 39, 285-302. doi:10.1111/1467-9566.12439

Gullette, M. M. (1988). Safe at last in the middle years: The invention of the midlife progress novel. Saul Bellow, Margaret Drabble, Anne Tyler, and John Updike. Berkeley, CA: University of California Press.

Gullette, M. M. (2004). Aged by culture. Chicago: The University of Chicago Press.

Hartung, H. (2016). Ageing, gender and illness in Anglophone literature: Narrating age in the Bildungsroman. London: Routledge.

Health Service Executive, Health and Wellbeing Division. "Healthy and Positive Ageing for All" Research Strategy, 2015-2019. Retrieved from https://www.hse.ie/eng/about/ who/healthwellbeing/our-priority-programmes/positive-ageing/ research-strategy-2015-2019/ (accessed March 2, 2018).

Higgs, P., \& Gilleard, C. (2015). Rethinking old age: Theorising the fourth age. London: Macmillan.

Hobbs, A. (2016). Aging masculinity in the American novel. Lanham: Rowman and Littlefield.

Johnston, J. (2009). Truth or fiction. London: Headline Review.

Johnston, J. (2015). Naming the stars. London: Tinder Press.

Kivnick, H. Q., \& Wells, C. K. (2014). Untapped richness in Erik H. Erikson's rootstock. The Gerontologist, 54, 40-50. doi:10.1093/geront/gnt123

Kreilkamp, V. (1998). The Anglo-Irish novel and the Big House. Syracuse, NY: Syracuse University Press.

Laslett, P. (1989). A fresh map of life: The emergence of the third age. London: Weidenfeld \& Nicolson.

Lloyd, L., Calnan, M., Cameron, A., Seymour, J. \& Smith, R. (2012). Identity in the fourth age: Perseverance, adaptation and maintaining dignity. Ageing \& Society, 34, 1-19. doi:10.1017/ S0144686X12000761

Marcoen, A., Coleman P. G. \& O’Hanlan, A. (2007). Psychological ageing. In J. Bond, S. M. Peace, F. Dittman-Kohli \& G. Westerhof (Eds.), Ageing in society: European perspectives on Gerontology (pp. 38-67). London: Sage.

Martin, P., da Rosa, G., \& Poon, L.W. (2011). The impact of life events on the oldest old. In L. W. Poon \& J. Cohen-Mansfield (Eds.), Understanding well-being in the oldest old (pp. 96-110). Cambridge: Cambridge University Press.

Moloney, C. (1998). An interview with Jennifer Johnston. Nua: Studies in Contemporary Irish Writing, 1, 139-149.

Neugarten, B. L. (1974). Age groups in American society and the rise of the young-old. The Annals of the American Academy of Political and Social Science, 415, 187-198. doi:10.1177/000271627441500114

Oró-Piqueras, M. (2016). The Loneliness of the aging in two contemporary novels. The Gerontologist, 56, 193-200. doi:10.1093/ geront/gnu033

Poon, L. W., \& Cohen-Mansfield, J. (2011). Toward new directions in the study of well-being among the oldest old. In L. W. Poon \& J. Cohen-Mansfield (Eds.), Understanding well-being in the oldest old (pp. 3-10). Cambridge: Cambridge University Press.

Riley, M. W. (1998). Letters to the editor. The Gerontologist, 38, 151. doi:10.1093/geront/38.2.151

Rooke, C. (1988). Hagar's old age: The stone angel as Vollendungsroman. In K. Gunnars (Ed.), Crossing the river: Essays in honour of Margaret Laurence (pp.25-42). Winnipeg, MB: Turnstone.

Rowe, J. W., \& Kahn, R. L. (1997). Successful aging. The Gerontologist, 37, 433-440. doi:10.1093/geront/37.4.433

Scarlata, J. (2014). Rethinking occupied Ireland: Gender and incarceration in contemporary Irish film. Syracuse, NY: Syracuse University Press.

Shmotkin, D., Shrira, A., \& Palgi, Y. (2011). Does trauma linger into old-old age? Using the holocaust experience as a paradigm. In L. W. Poon \& J. Cohen-Mansfield (Eds.), Understanding well-being in the oldest old (pp. 81-95). Cambridge: Cambridge University Press.

Smith, J., Borchelt, M., Maier, H., \& Jopp, D. (2002). Health and well-being in the young old and oldest old. Journal of Social Issues, 58, 715-732. doi:10.1111/1540-4560.00286

Sweeting, H. N., \& Gilhooly, M. L. (1992). Doctor, am I dead? A review of social death in modern societies. Omega, 24, 251269. doi:10.2190/10n6-p489-nr8n-jq6k

Sweeting, H. \& Gilhooly, M. (1997). Dementia and the phenomenon of social death. Sociology of Death \& Illness, 19, 93-117. doi:10.1111/j.1467-9566.1997.tb00017.x

Swinnen, A. \& Schweda, M. (Eds.). (2015). Popularizing dementia: Public expressions and representations of forgetfulness. Bielefeld: Transcript.

Tomassini, C. (2005). The demographic characteristics of the oldest old in the United Kingdom. In Office for National Statistics, Population Trends, 120, 15-22.

Tornstam, L. (1997). Life crises and gerotranscendence. Journal of Aging and Identity, 2, 117-131. doi:10.1016/ S0890-4065(97)90018-9

United Nations. (1956). The aging of populations and its economic and social implications. Population Studies, no. 26. New York.

UN, Population Division. (2002). World population ageing 1950-2050. Executive summary. New York. Retrieved from http://www.un.org/esa/population/publications/worldageing19502050/pdf/62executivesummary_english.pdf (accessed April 9, 2018).

UN, Population Division. (2015). World population ageing 2015. New York. Retrieved from http://www.un.org/en/development/ desa/population/publications/pdf/ageing/WPA2015_Report.pdf (accessed April 9, 2018).

Waxman, B. F. (2010). Literary texts and literary criticism team up against ageism. In T. R. Cole, R. E. Ray \& R. Kastenbaum (Eds.), A guide to humanistic studies in aging: What does it mean to grow old? (pp. 83-104). Baltimore: John Hopkins University.

Woodward, K. (1999). Introduction. In K. Woodward (Ed.), Figuring age: Women, bodies, generations (pp. ix-xxix). Bloomington: Indiana University Press.

Wyatt-Brown, A. M. (2010). Resilience and creativity in aging: The realms of silver. In T. R. Cole, R. E. Ray \& R. Kastenbaum (Eds.), A guide to humanistic studies in aging: What does it mean to grow old? (pp. 57-82). Baltimore: John Hopkins University.

Yeats, W. B. (1968). Sailing to Byzantium. In A. N. Jeffares (Ed.), W. B. Yeats: Selected poetry (pp. 104-105). London: Macmillan. 